\title{
Obstacles the Development of Microfinance Institutions for Beef Cattle Farmers in Indonesia
}

\author{
Aslina Asnawi ${ }^{1}$, Andi Amidah Amrawaty ${ }^{2}$, Nirwana ${ }^{2}$ \\ 1 Department of Socio Economics of Animal Science, Faculty of Animal Science, Hasanuddin University, Makassar \\ 2 Department of Accounting, Faculty of Economics and Business, Hasanuddin University, Makassar J1. Perintis Kemerdekaan, Makassar 90245, Indonesia
}

Correspondence Author: Aslina Asnawi, Department of Socio Economics of Animal Science, Faculty of Animal Science, Hasanuddin University, Makassar Email: aslinaasnawi@unhas.ac.id

Received date: 28 August 2019, Accepted date: 15 November 2019, Online date: 26 November 2019

Copyright: (C) 2019 Aslina Asnawi et al., This is an open-access article distributed under the terms of the Creative Commons Attribution License, which permits unrestricted use, distribution, and reproduction in any medium, provided the original author and source are credited.

\begin{abstract}
One of the efforts made to meet the needs of meat consumption and fulfillment of animal protein in Indonesia is to encourage increased beef cattle breeding business. But one of the obstacles faced by farmers is the lack of capital to increase their business capacity. Financing from formal financial institutions is not easy because it requires collateral which is generally not owned by the farmers, the procedure is long and the location is relatively far from where the farmer lives, making it difficult for farmers to access financing from the financial institution. Microfinance institutions (MFIs) in rural areas are one alternative to overcome financing constraints due to low access to formal financing institutions. This study aims to identify the determinants faced in the development of MFIs for farmers in rural areas. The research population was all members of a combined farmers group who were active in an MFIs, around 270 people. The number sampled was 73 people. Data collection was conducted by interviews using questionnaires and data collection using the Delphi method. Data were analyzed using descriptive statistics and quantitative descriptive analysis. The results showed that the determinants or factors that hindered the development of MFIs were: the ability to collect and distribute funds to its members, low member participation, payment of loan installments, managerial ability and commitment of the management in managing funds. MFIs need to receive support from the government and the community so that they can survive as an institution that can facilitate farmers in overcoming capital constraints at the village level.
\end{abstract}

Keywords: Beef Cattle Farmers, Microfinance Institutions, Obstacles

\section{INTRODUCTION}

Financing is one of the obstacles that face cattle farmers, along with the usual constraints of productivity, disease, and availability of feed. Loans are needed to finance working capital as well as for investment activities. Sources of financing that can be accessed by farmers can include formal and informal financing institutions.

Formal financial institutions can be banks and the government, through grants distributed by an executing bank. The banking sector provides several types of loans, e.g., business and program loans. However, not all farmers can access financing, which is caused by several factors. These include lengthy procedures, collateral requirements, and lack of information about funding because farmers are often located relatively far from formal financing institutions as [3], [18], in addition to highinterest rates as [15], low education levels, and the need for an increased role for agricultural extension agents in the distribution of information as [22], emphasized the lack of knowledge, inadequate credit supply, high-interest rates, and default rates as the primary factors hindering smallholder farmer access to credit; as [21] that unavailability of collateral securities, small loan amounts and delay in the release of agricultural loans were also significant challenges. Therefore, to increase farmers' enthusiasm for financing, the government must facilitate funding to farmers with subsidized interest rates as [16].

This condition encourages farmers to look for other sources of financing besides formal institutions. Therefore, the existence of informal financing institutions is very necessary. One example is microfinancing institutions (MFIs), which operate outside the regulation and supervision of government institutions so that they are classified as informal financing institutions.

MFIs, according to the definition of the Asian Development Bank (ADB), are institutions that provide storage services (deposits), loans, payments for various service payments (payment services) and money transfers aimed at the poor and small entrepreneurs. In Indonesian Law No. 1 of 2013 and as [10] that MFIs are defined as financial institutions that are specifically established to provide business development services and community empowerment, either through loans or financing in microscale businesses to members and the community, savings management, and provision of services business development consultations that are not solely for profit. 
MFIs have the opportunity to grow and develop in rural areas because they have a geographical, social and cultural closeness with farmers. For MFIs located in rural areas, there is a personal relationship between farmers and MFIs managers, who understand the culture and character of the community so that it is possible to grow in rural areas strongly. Trust and simple procedures provide space for farmers to utilize MFIs.

There are several examples of MFIs developing in Indonesia, especially in sub-districts and rural areas. The names of these MFIs are often named according to their respective regions such as the Village Credit Agency (Badan Kredit desa/BKD) in East Java, Central Java, Yogyakarta, and West Java; Village Credit Institutions (Lembaga Perkreditan Desa/LPD) in Bali, Rural Credit Business Entities (Badan usaha Kredit Pedesaan/BUKP) in Yogyakarta, Small Business Financing Institutions (Lembaga Pembiayaaan Usaha Kecil/LPUK) in South Kalimantan, Rural Credit Institutions (Lembaga Kredit Pedesaan/LKP) in West Nusa Tenggara, Subdistrict Credit Institutions (Lembaga Kredit Kecamatan/LKK in Aceh, Baitul Maal wat Tamwil (BMT) in almost all regions of Indonesia as [1]. Especially in South Sulawesi, this BMT has developed quite rapidly.

In South Sulawesi, Indonesia also developed an Agribusiness Micro Finance Institution, which is a financial institution at the farm level coordinated by the combinations of farmers groups, the recipient of the Society's Public Aid for Agribusiness Development in Rural Areas. This program is based on government policy through the Ministry of Agriculture in 2008 concerning Agribusiness Development in Rural Areas. It refers to the basic pattern stipulated in the Minister of Agriculture Regulation No.16/Permentan/OT.140/3/2009 and refined as [11] through the Minister of Agriculture Regulation No.06/Permentan/OT.140/2/2015 concerning General Guidelines for the Development of Rural Agribusiness Enterprises namely education and training for business development, assistance and provision of business capital assistance facilities to farmers coordinated by the combined farmers groups.

After their initial development, some MFIs have survived, but not infrequently many MFIs are found to be unsustainable, even though the funding goal is perfect, especially if its formation is from and by its members. This also applies in the area of South Sulawesi. There has been a positive response from farmers to the existence of MFIs in rural areas because the requirements and procedures were easy and helped overcome the financing constraints for farmers. Funds obtained by breeders from MFIs then their utilization depends on the farmers' needs themselves, for example: buying seeds, repairing cages, or buying animal feed. Generally, these funds are intended to finance operational needs, not just for investment. One factor is that the amount of funds that can be obtained from MFIs is not too large. The reason is that it needs to pay attention to other MFIs members who need funds. So even though the number is not relatively large, it can meet the needs of more members of the MFIs.

Whereas quite some previous studies explained that MFIs at the village level play a role in encouraging the strengthening of livestock farmer group institutions in rural areas and alleviating poverty as [4], [12] explained that credit beneficiaries $(\mathrm{CB})$ in microfinance institutions have high agricultural productivity compared to non-credit beneficiaries (NBCs). [24] revealed that MFIs services had addressed the needs of rural agriculture and yield a positive impact on their livelihood.

One of the benefits of a microfinance institution is that it can solve the problem of financing for farmers. But apparently, not all MFIs in rural areas can survive as [5]. There are some obstacles faced by these MFIs, which inhibits growth in rural areas. The research aimed to explore the obstacles to the development of MFIs in rural areas, especially for beef cattle farmers. This research is essential because the MFIs play a role but on the other hand, some of them do not survive. This is the background of this study.

\section{METHODS}

This research was conducted in Sinjai regency. This area was determined purposively because in this area there are Agribusiness Microfinance Institutions which still exist today. The subject of the study was a member of the farmer's group combination that used the Agribusiness Microfinance Institution in their area. The study population was taken from all beef cattle farmers in East Sinjai District; in this area, there was two farmers group combination who were very active and continued the activities of MFIs that had been formed before even though the Rural Agribusiness Development Fund was gone. The number of members was 140 people in Patalasang Village and 130 people in Biroro Village, so the total population was 270 people. Sampling using the Slovin formula as [25], namely:

$$
\mathrm{n}=\frac{N}{1+N \cdot e^{2}}
$$

where: $\mathrm{n}=$ number of samples, $\mathrm{N}=$ number of population, $e^{2}=$ preparation (the allowance is set at $10 \%$ ).

The proper number of samples was 73 people using this formula. The sample used in this study was 73 farmers. The number of samples in each village needed is:

$$
\begin{aligned}
& \text { a. Patalassang Village }=\frac{140}{270} \times 73=38 \text { people } \\
& \text { b. Biroro Village } \quad=\frac{140}{270} \times 73=35 \text { people }
\end{aligned}
$$

Determination of the sample used a simple random sampling method where the sample is taken randomly by drawing the name of the selected farmer. Exploratory methods were also used to explore in-depth the obstacles faced by the farmer group combination. Interviews with the board of the farmer's group combination were conducted for two resource persons, namely the Chair and Secretary of farmers group combination. Interviews with members of livestock farmer groups were carried out to 8 people each, of 5 men and three women. 
Data were analyzed using descriptive statistics and quantitative descriptive analysis. The Delphi method was used in data collection in this study. This method uses a series of questionnaires. In the first phase, the questionnaire was made in an open format submitted to explore the problems faced in the development of microfinance institutions in rural areas. Respondents were given the freedom to write down the inhibiting factors for the development of the MFI. At this stage, as much information is collected as possible from the respondent group.

The second questionnaire was conducted semi-openly and was given to respondents who had answered the questionnaire at the first stage to check whether there were significant disagreements between groups of respondents. In this case, the respondent is only given the opportunity to choose the answers that have been prepared from the results of the first questionnaire. Based on these choices, the respondent determines the answer about which factor is the most influential given the value of 1 and the least influential is given a score of 5. The same applies to the next questionnaire so that the simplification of the factors that most influence the development of MFIs in rural areas according to each score. Descriptive analysis based on inhibiting factors for the development of MFIs that are assisted by using the Delphi method as [13], [17].

\section{RESULTS}

\section{Respondent Demographics}

The research questionnaire was aimed at 73 people who were willing to fill out the survey. Respondents' demographics can be seen in Table 1.

Table 1. Respondents Demographics

\begin{tabular}{llr}
\hline Demography & Attribute & Percentage (\%) \\
\hline Sex & Male & 97.26 \\
Age (years) & Female & 2.74 \\
& $20-30$ & 28.77 \\
& $31-40$ & 27.39 \\
& $41-50$ & 30.14 \\
& $51-60$ & 12.33 \\
Education & $61-70$ & 1.37 \\
& No graduate elementary school & 9.59 \\
& Elementary school & 19.18 \\
& Junior high school & 21.92 \\
& Senior high school & 39.73 \\
& Bachelor & 9.59 \\
Farm experience (years) & $3-12$ & 34.25 \\
& $13-22$ & 50.68 \\
& $23-32$ & 12.33 \\
& $33-42$ & 2.74 \\
\hline
\end{tabular}

Most respondents in this study were male. This is related to raising cattle in the area carried out by men. This is because raising cattle requires strong energy such as taking forage to provide food with every day, herding, and even cleaning the cattle. If seen from the age of the respondents, they were dominated by generations 41-50 years, 20-30 years and 31-40 years, respectively $30.14 \%, 28.77 \%$ and $27.39 \%$. Therefore it can be said that the majority of respondents are in productive age, so they are very supportive of the continuity of beef cattle farming. The level of education of respondents was already quite high because most of them graduated from high school and junior high school. These conditions strongly support the ability of group members and influence the managerial skills of members and administrators of microfinance institutions. Respondents in this study have a relatively long breeding experience because generally, they have been breeding between 13 and 22 years. This condition also supports the management of the livestock business that is carried out, and the experience of livestock will affect their skills in raising livestock.

\section{The Obstacles against Agribusiness Micro Finance Institutions in Rural Area}

There are three stages of data collected to identify factors that inhibit the development of Micro Finance Institutions in beef cattle farming in the research area. The first phase is using a questionnaire with an open question format, where respondents were given the freedom to write down some obstacles that inhibited development.

In the first phase, seven factors were obtained, namely: the level of education of members and MFIs management, the commitment of management in managing funds, the participation of members, ability to collect and distribute funds to members of farmers group, loan instalment payments, the managerial expertise of management, and market access and information.

Then in the second stage, from the seven factors that have been identified, the respondents then assessed as to what according to them is the most inhibiting development of Microfinance Institutions in rural areas. Factors that are considered to be the most influential are given the smallest value of one and the least influential given the highest score. The assessment given is then sorted based on the score that each factor has as shown in Table 2. 
Table 2. Second Stage Value Score Regarding Inhibiting Factors Development of Microfinance Institutions in Rural Areas

\begin{tabular}{llcc}
\hline No & \multicolumn{2}{c}{ Inhibiting factors } & \multicolumn{2}{c}{ Assessment } \\
\cline { 3 - 4 } & & Score & Value \\
\hline 1. & Level of education of members and MFIs management & 394 & 2 \\
2. & The commitment of MFIs management in managing funds & 360 & 3 \\
3. & Participation of MFIs members & 228 & 6 \\
4. & Ability to collect and distribute funds & 166 & 7 \\
5. & Payment of loan instalments & 247 & 5 \\
6. & MFIs management managerial ability & 252 & 4 \\
7. & Market access and information & 397 & 1 \\
\hline
\end{tabular}

Based on the assessment in the second stage, the third stage is proceeded to by giving 5 predetermined answer categories, namely the most influential 1 and 5 for the less influential. From the answers and judgments given, several factors were inhibited to develop the MFIs, as shown in Table 3.

Table 3. Third Stage Value Score Regarding Inhibiting Factors Development of Micro Finance Institutions in Rural Areas

\begin{tabular}{llcc}
\hline No & \multicolumn{2}{c}{ Inhibiting factors } & \multicolumn{2}{c}{ Assessment } \\
\cline { 3 - 4 } & & 286 & Score \\
\hline 1. & The commitment of MFIs management in managing funds & 232 & 2 \\
2. & MFIs management managerial ability & 215 & 3 \\
3. & Payment of loan instalments & 205 & 4 \\
4. & Participation of MFIs members & 159 & 5 \\
5. & Ability to collect and distribute funds & & \\
\hline
\end{tabular}

There were five obstacles to the success of the Micro Finance Institution had identified in this study. The first was the commitment of the MFIs board in managing funds. Not infrequently there is also a person who does not distribute funds in microfinance institutions by the designation, for example, spending the funds to finance activities outside of the cattle breeding business that is run. This can be a cause of MFIs not being sustainable. Therefore, group administrators must have a sense of responsibility and good character so that they can avoid these things happening. Also, there needs to be a change in mindset for farmers who consider that if there is assistance from the government, it does not need to be returned. As [14] stated that the wrong understanding of the funds given to farmers was considered as assistance that did not need to be returned.

The second was the managerial ability of the MFIs committee. The success of an MFIs is also determined by the administrative ability of management regarding managing institutional activities, managing funds and maintaining relationships with members. The background and level of education greatly influence this managerial ability. The level of education supports the ability to communicate, the ability to manage the organization and make good financial records. As [20] that the factors that influence the efficiency of agribusiness microfinance institutions are the level of education of managers, age, service time and the number of managers.

The third was the payment of loan instalments. Continuity in paying loan instalments will affect the ability of capital from agribusiness microfinance institutions. The causes also vary because they have experienced disasters such as livestock being stolen or dead but some for unclear reasons. The number of funds lent was IDR 5,000,000 to IDR 7,000,000.00 per member. Aside from being in the form of money, it can also be in the form of 1 head of cattle, which is equivalent to the maximum amount of funds that can be borrowed. The interest rate charged to members is $1.5 \%$ per year. The smoothness in repaying loans greatly determines the success rate of microfinance institutions in rural areas.

The fourth was the participation of MFIs members. This one was very important because more and more people were involved, this shows the activeness of the institution. This also affects the ability and availability of capital in the institution. Therefore, the full participation of members is expected. This can be illustrated if group members only use MFIs when they need funds but are not followed by any regularity in depositing mandatory savings and principal savings. This will reduce the ability of MFIs to serve other members who need loans. Also, high farmer involvement in the object of research is because the microfinance institution has provided evidence that it can be used as a place to obtain loans even with a small platform. This is in line with [19] stated, that the loan model offered by financial providers will influence farmers' participation in accessing capital.

The last one was the ability to collect and distribute funds. This is related to the authority possessed by an MFIs that may not raise funds outside of its members. In addition to funds obtained from development in rural areas that have been obtained previously, the source of funds is also sourced from its members in the form of principal savings, mandatory savings and voluntary savings. The greater the amount of savings provided by its members, the higher the ability and availability of funds. This matter will have an impact on the ability to channel funds depending on the availability of the MFIs cash funding. This, of course, will have an impact on the ability to direct funds a great deal. This is according to [23] that one of the operational constraints faced by MFIs is the ability and magnitude of capital depending on the number of members and the masses that are owned, thus influencing the development of the microfinance institution. 
MFIs have great potential in distributing funds to farmers because they are more accessible to farmers because they are in rural areas. The amount of capital needed by farmers is generally not large so that it is in line with the ability to finance microfinance institutions. The relationship between farmers as members of farmer groups is close to the management of MFIs so that there is trust in each other. This is in line with [2] that MFIs were easily accessible to farmers because they are generally located in rural areas. Also, the process is not long, less credit need were characteristics of the farm so that they are in line with the financial capability of the MFIs, the timeliness of the location is close, and there were social-cultural linkages and personalemotional relationships that could reduce moral hazard in credit repayments.

Therefore, factors that are considered as obstacles need to be minimized to strengthen the role of microfinance institutions especially in alleviating poverty in the rural area as [9]. Strong microfinance institutions will have a positive impact on the development of micro-enterprises in all areas.

\section{CONCLUSION}

Some of the obstacles faced in the development of microfinance institutions in rural areas are the ability to collect and channel funds from and for its members, participation of members, smooth payment of loan instalments, the managerial ability of management and commitment of the management in managing funds. Therefore, factors that are considered as obstacles need to be minimized to strengthen the role of microfinance institutions in rural areas, especially in alleviating poverty.

\section{CONFLICT OF INTEREST}

We certify that there is no conflict of interest, i.e., any financial, personal, or other relationship with other people or organization related to the material discussed in the manuscript.

\section{ACKNOWLEDGEMENT}

This research was funded by a grant the $1^{\text {st }}$ and the $2^{\text {nd }}$ year of Penelitian Terapan Unggulan Perguruan Tinggi (PTUPT), 2018, Ministry of Research, Technology, and Higher Education, the Republic of Indonesia with decision letter No. 01/E/KPT/2018 dated January 3, 2018 and contract No. 1509/Un4.21/PL.00.00/2018 dated March 21, $2018 . \quad$ Ministry of Research, Technology, and Higher Education, Republic of Indonesia with decision letter No. T/140/E3/RA.00/2019 dated February 25, 2019 and contract No. 2252/UN4.21/PL.00.00/2019 dated May 6, 2019.

\section{REFERENCES}

[1] Anwar, A.I. 2016. Microfinance Institutions (MFIs) and rural economic development in South Sulawesi. The economic bureau of the governor of the Government of South Sulawesi.

[2] Ashari. 2006. Potential of Microfinance Institutions (MFIs) in Rural Economic Development and Development Policy. Agricultural Policy Analysis. Volume 4 No. 2: 146-164.

[3] Asnawi, A. 2013. Determinant of Funding Accessibility and its Impacts to the Performance of Beef-Cow Breeding Enterprises in South Sulawesi Province, Indonesia. European Journal of Business and Management. Vol. 5 No. 9: 7784.

[4] Asnawi, A., A.A. Amrawaty., Nirwana, Amrullah and R. Sudarmadji. 2018. The Role of Agribusiness Microfinance Institutions Overcoming Capital Constraints for Farmers in Rural. Proceedings of The Third of the National Seminar on Livestock Resurrection. Department of Animal Husbandry, Faculty of Animal Husbandry and Agriculture. Diponegoro University, Semarang. May 3, 2018.

[5] Asnawi, A., A.A. Amrawaty., and Nirwana. 2018. Response of Farmers about the Existence of Agribusiness Microfinance Institutions in Rural Areas. Proceedings of the National seminar The Association of Indonesian Socio-Economic Sciences III in the Faculty of Animal Husbandry, Sam Ratulangi University. Manado, 6-7 September 2018.

[6] Agriculture Department. 2009. General Guidelines for Rural Agribusiness Development. Deptan Press, Jakarta.

[7] Agriculture Department. 2009. Technical Guidelines for Distribution and Utilization of Rural Agribusiness Development Funds. Deptan Press, Jakarta.

[8] Baskara, I.G.K. 2013. Microfinance Institutions in Indonesia. Economic Study Bulletin Journal. Vol. 18, No. 2: $114-125$.

[9] Dahir, A.M. 2015. The Challenges Facing Microfinance Institutions in Poverty Eradication: A Case Study. International Journal of Humanities Social Sciences and Education. Volume 2, Issue 2: 56-62.

[10] Directorate of Agricultural Financing. 2014. concerning Microfinance Institutions. People's Representative Council, Indonesia.

[11] Directorate of Agricultural Financing. 2015. Development of Agribusiness Microfinance Institutions at the Rural Agribusiness Development Farmers Group Association 2015. Directorate of Agricultural Financing, Directorate General of Agricultural Infrastructure and Facilities, Ministry of Agriculture, Jakarta.

[12] Girabi, F and A.E.G. Mwakaje. 2013. Impact of microfinance on smallholder farm productivity in Tanzania: The case of Iramba district. Asian Economic and Financial Review. Vol. 3(2): 227-242.

[13] Gordon, T.J., 1994. The Delphi Method. Millenium. London.

[14] Hermawan H and Andrianyta H. 2012. Agribusiness Microfinance Institution. Breakthrough in Strengthening Institutions and Financing Agriculture in the Rural Area. Analysis of Agricultural Policies. Vol 10 (2): 143-158.

[15] Hyz, A.B. 2011. Small and Medium Enterprises (SMEs) in Greece - Barried in Access to Banking Services, An Empirical Investigation. International Journal of Business and Social Science. Vol. 2. No. 2. 
[16] Kalangi, L.S., Y. Syaukat, S.U.KUntjoro, and A.Priyanti. 2014. Technical Efficiency of Beef Cattle Business in East Java Province. Media Peternakan. Vol 37(2): 136-142.

[17] Linstone, H and M. Turoff. 2002. The Delphi Method Techniques and Application. Murray Turoff \& Harold A. Linstone Inc., London.

[18] Nurmanaf, A.R. 2007. Informal Institution for Micro Financing Closer to Farmers. Agricultural Policy Analysis. Center for Agricultural Socio Economic and Policy Analysis. Vol. 5 No. 2. June. Pp 99-109.

[19] Pederson, G. 2012. Microeconomic Impact of a State-funded Farmer Loan Program. Agricultural Finance Review 72 (1): 5 21.

[20] Saleh Y, Mulyo JH, Rahayu LW. 2012. The efficiency of Agribusiness Microfinance Institutions. A Combination of Farmer Groups in the Development of Rural Agribusiness. Case Study in Bantul District in 2012. Agro Economic Journals. 30 (2): $129-144$.

[21] Sulemana, A and S.A. Adjei. 2015. Microfinance Impact on Agricultural Production In Developing Countries - A Study of The Pru District in Ghana. International Journal of Academic Research and Reflection. Vol. 3 No 3: 26-44.

[22] Supanggih, D and S. Widodo. 2013. Accessibility of farmers to financial institutions (Case study on farmers in Sidodadi Village, Sukosewu sub district, Bojonegoro Regency). Agriekonomika Journal. Vol.2 No.2: 163-173.

[23] Susila, I. 2007. Analysis of the Efficiency of Microfinance Institutions. Economic Development Jounral. Vol. 8, No. 2: 223-242.

[24] Ud Din, M.Z. 2011. Microfinance Services for rural agriculture in Pakistan and Bangladesh. Faculty of Natural Resources and Agricultural Sciences Department of Urban and Rural Development Rural Development and Natural Resource Management. Swedish University of Agricultural Sciences.

[25] Umar, H. 2001. Research Methods for Thesis and Thesis. Jakarta: PT. Raja Grafindo Persada. 